\title{
Extrapolating Bypass Protein Potential of Treated Soybean Meal by In Situ Degradation in Rumen- Fistulated Brahman Cattle
}

\author{
Angelo Francis F. Atole and Lolito C. Bestil \\ Department of Animal Science, Visayas State University \\ Visca, Baybay City, Leyte 6521-A, Philippines
}

\section{ABSTRACT}

Loss of dietary proteins through microbial fermentation in the rumen may deprive the ruminant animals of valuable supply of amino acids at the intestinal level. This study was conducted to determine the effectiveness of three treatment methods (heat, formaldehyde, and tannic acid) in protecting dietary protein in soybean meal (SBM) from excessive microbial degradation in the rumen to extrapolate its bypass protein potential. The treated SBM samples were incubated for 24,48 , and $72 \mathrm{hr}$ in rumen-fistulated cattle.

Results showed that the different treatment methods significantly reduced the rumen degradation of dry matter (DM) in SBM for 24-hr $(\mathrm{p}<0.01), 48-\mathrm{hr}(\mathrm{p}<0.01)$ and $72-\mathrm{hr}(\mathrm{p}<0.05)$ incubation, with tannic acid treatment showing the least. In terms of crude protein (CP) degradation, all the treatment methods showed significant reduction in 24-hr $(\mathrm{p}<0.01)$ while heat and formaldehyde in 48-hr $(\mathrm{p}<0.05)$ incubation, while tannic acid treatment did not differ significantly with that of the untreated, indicating their greater potential than tannic acid in protecting dietary protein from microbial degradation in the rumen. A similar pattern of differences were observed as that of actual values in terms of rates of DM and CP degradation. Overall, heat and formaldehyde treatments can effectively increase the potential of dietary protein to supply the needed amino acids in the intestines.

Key words: Formaldehyde, heat, tannic acid, soybean meal, in situ degradation

Correspondence: A.F.F. Atole Address: Department of Animal Science, Visca, Baybay City, Leyte, 6521-A, Philippines.E-mail: director_choy@yahoo.com

DOI: $10.32945 /$ atr3614.2014 


\section{INTRODUCTION}

Ruminants that are in certain physiological conditions require high amounts of dietary protein that are not degraded in the rumen (ARC, 1984), and will depend on both microbial protein and dietary rumen undegradable protein (RUP) that are digested and absorbed in the small intestines (Nobar et al., 2009). Because of the great demand for protein to support higher levels of production, these animals need to be supplemented with bypass protein sources to satisfy the amino acid (AA) requirements in the small intestines since microbial protein has insufficient amounts of essential amino acids (EAAs) needed for growth, milk, or wool production (Nimrick et al., 1970). The rate and extent of protein degradation in the rumen from feed supplements can be regulated to complement the protein supply from microbial synthesis (Soltan, 2009) to increase the supply of RUP that reaches the intestines as bypass protein which influences the availability of amino acids (AAs) depending on the total protein supply and amino acid (AA) composition (NRC, 2001). Therefore, overall efficiency of animal performance can be improved if the readily degradable protein is protected from degradation in the rumen, but still be made available for digestion in the intestines (Wina et al., 2008).

Soybean meal (SBM), being readily available and very palatable, and of high quality in terms of AA balance, is the most commonly used protein source in cattle diets (Lin and Kung, 1997). Compared to oilseed meals it contains higher EAAs making it the most commonly used protein supplement for dairy cattle in North America (USDA-NASS, 2004); its EAAs constitute $46.7 \%$ of the crude protein (CP) as compared to other plant protein sources used in animal diets (Schwab, 1995). Despite its potential as good source of quality protein for all classes of ruminants at different production levels, its high degradability in the rumen limits its use as source of AA to supplement those produced from microbial protein synthesis and from other protein supplements in the diet (Bateman and Clark, 2000). Thus, SBM must be subjected to treatment methods that protect its protein from excessive microbial fermentation to directly benefit the animals of its high quality protein and AA profile. Several treatment methods have been tested to reduce the microbial degradation of protein from supplements in the rumen such as: heat (Nishimuta et al., 1974; Leng, 1997; Lin and Kung, 1997), tannin (Nishimuta et al., 1974; Leng, 1997; Martinez et al., 2004), and formaldehyde (Nishimuta et al., 1974; Leng, 1997). Heat treatment produces amino-sugar complex due to 
Maillard reaction resulting to resistance of protein to enzymatic hydrolysis (Lin and Kung, 1997). Tannin (tannic acid) forms hydrogen bonds with protein that are stable between pH 3.5 to 8 (Mueller-Harvey and McAllan, 1992) that inhibit microbial enzymes in the rumen (Bae et al., 1993; Jones et al., 1994). Formalin (formaldehyde) alters bacterial population in the rumen and forms cross links between protein chains (Woolford, 1975). This study assessed the effectiveness of the different treatment methods in reducing CP degradation in situ (in the rumen) of SBM as basis for extrapolating its potential as source of bypass protein.

\section{MATERIALS AND METHODS}

\section{Preparation of the animal}

A rumen cannula-fitted (Bar Diamond Lane, Parma, ID, U.S.A.) yearling Brahman bull weighing $200 \mathrm{~kg}$ bodyweight (BW) was used in the study. A month before the in situ trial, the animal was confined, closely monitored for any unhealthy condition, and was treated against internal and external parasites with Albendazole (Pfizer, Inc.) at $1 \mathrm{ml} / 10 \mathrm{~kg}$ BW given orally and with Ivermectin (Merial, Inc.) at $1 \mathrm{ml} / 50 \mathrm{~kg}$ BW injected subcutaneously at one week interval. The animal was also adjusted to the diet containing the supplemental SBM to be tested.

\section{Protection of the dietary soybean meal}

Soybean meal was treated with heat $(\mathrm{H})$, formaldehyde $(\mathrm{F})$, and tannic acid (T). Heat treatment was accomplished by spreading the SBM in a tray at about 1 inch thick and heated for four hours at $149^{\circ} \mathrm{C}$ in a force-draft oven (Glimp et al., 1967). Formaldehyde treatment of SBM was done by adding $10 \mathrm{ml}$ of formalin solution (10\% concentration) per $100 \mathrm{~g}$ of SBM and mixed thoroughly for about $30 \mathrm{~min}$ (Hemsley et al., 1970), then stored at room temperature. Tannic acid treatment was accomplished by spraying plain water at $5 \%$ of the as-fed weight of SBM then mixing thoroughly for about $30 \mathrm{~min}$, and sprinkling with tannic acid powder (Merck, Germany) at $9 \%$ of the as-fed weight of SBM then thoroughly mixing for another $30 \mathrm{~min}$ (Hatfield et al., 1969). The chemically-treated SBM were stored for three days in a coarse cloth container at room temperature to equilibrate with air (Nishimuta et al., 1974). The heat-treated (H-SBM), formaldehyde-treated (F-SBM), and tannic acid-treated SBM (T-SBM) were compared with the 
untreated (U-SBM) in an in situ digestion trial. The treatment procedures were done at the Animal Nutrition Laboratory of the Department of Animal Science(DAS), Visayas State University (VSU), Baybay City, Leyte, Philippines.

\section{Feeding the experimental animal}

The animal was fed with a diet containing $70 \%$ basal Napier grass (Pennisetum purpureum Schumach.) soilage chopped to about four inches long and 30\% SBM for one month before the in situ trial. The 30\% level of treated SBM in the diet was based on the recommendation of Preston (1986) on the use of supplements high in protein content. The total feed offered was based on the required dry matter intake (DMI) of $5.4 \mathrm{~kg} /$ day for a 200-kg BW cattle (Kearl, 1982). A week before the trial, the total feed offered was gradually reduced into half to ensure that nylon bags reach the ventral sac of the rumen and to make its recovery easier (Playne et al., 1978). Feeding was done daily at 7:00 AM and 4:00 PM with free access to drinking water.

\section{Rumen incubation of treated soybean meal and chemical analysis}

Nylon bags (pore size of $\pm 53 \mu \mathrm{m}$ ) measuring $5 \times 10 \mathrm{~cm}$ (Bar Diamond Lane, Parma, Idaho, USA) used in the study were oven-dried at $65^{\circ} \mathrm{C}$ for 30 min and weighed right away based on the procedures of Osuji et al. (1993). Approximately $4 \mathrm{~g}$ dry weight each of the dietary treatments (treated and untreated SBM) were placed inside the nylon bags and heat-sealed. These were then placed inside a lingerie bag weighed with stainless steel pieces to prevent the nylon bags from floating once placed inside the rumen which may give variable degradation rates (Preston, 1986). The order of incubation adopted the "sequential addition method" to lessen disturbance to the rumen environment (Osuji et al., 1993). This was done by putting in first the samples for 72-hr incubation, followed by the samples for 48-hr incubation on the next day, and lastly the samples for 24$\mathrm{hr}$ incubation on the third day, then all the samples were recovered at the same time on the fourth day. The recovered nylon bags were then washed for 30 min under running tap water, scrubbing gently between the thumb and fingers until the water ran clear. The washed nylon bags containing the samples were then oven-dried at $65^{\circ} \mathrm{C}$ for 48 hours and were hot-weighed using a digital analytical balance (Sartorius, AG Gottingen) to obtain the 
weight of the DM residue (Osuji et al., 1993). Crude protein was determined from nitrogen analysis in the macro-Kjeldahl digestion and distillation apparatus, derived by multiplying the percent nitrogen $(\% \mathrm{~N})$ with the factor 6.25 based on $16 \% \mathrm{~N}$ content, on the average, of protein sources (AOAC, 1993).

The in situ experiment was conducted following a randomized complete block design (RCBD) with four blocks based on four periods of placing 12 nylon bags, representing the four treatments and three incubation periods, in the rumen. The experiment was conducted at the Beef Cattle Project of the DAS, VSU, Baybay City, Leyte, Philippines.

\section{Data gathered and statistical analysis}

Dry matter and crude protein degradation (CPD) of the treated SBM were determined using the following formula:

DMD \% = Drywt. before incubation-Drywt.after incubation $\times 100$ Dry wt. before incubation

Where: Dry wt. before incubation $=$ Sample wt. $\mathrm{x} \% \mathrm{DM}$ of sample Dry wt. after incubation $=($ Dry wt. + Nylon Bag wt. $)-$ Nylon Bag wt.

$\mathrm{CPD} \%=\underline{\text { CP before incubation }-\mathrm{CP} \text { afterincubation }} \times 100$ CP before incubation

Where: $\quad$ CP before incubation $=$ Sample wt . before incubation $\mathrm{x} \% \mathrm{CP}$ on DM basis $\mathrm{CP}$ after incubation $=$ Sample wt. after incubation $\mathrm{x} \% \mathrm{CP}$ on DM basis

The degradation rates of DM and $\mathrm{CP}$ were calculated by dividing the actual values of dry matter degradation (DMD) and CPD with the various incubation periods $(24,48$ and $72 \mathrm{hr})$.

Data were analyzed using two-way analysis of variance, and comparison of treatment means was done by Tukey's Honestly Significant Difference (HSD) Test using the Statistical Package for Social Sciences (SPSS) version 17 computer program. 


\section{RESULTS AND DISCUSSION}

\section{In situ dry matter degradation of treated soybean meal}

There was a significant reduction in DMD for the treated SBM as compared with the untreated at 24-hr, 48-hr, and 72-hr incubation (Table 1). Comparing treatment methods, H-SBM and F-SBM appeared to be more effective than T-SBM in reducing DMD in the rumen across incubation periods. Heat treatment appeared to be the most effective in reducing excessive DMD even until 72 hours $(p<0.05)$ of incubation, which is good in feeding situations where feed stays longer in the reticulo-rumen. Dry matter degradation rates (DMDR) decreased over time (period of incubation), but the pattern of differences among treatments across periods appeared to be similar as that of actual DMD values.

Table 1. Dry matter degradation and disappearance rate of heat-, formaldehyde-, and tannic acidtreated SBM at various incubation periods.

\begin{tabular}{lcccccc}
\hline \multirow{2}{*}{ Treatments } & \multicolumn{3}{c}{ Dry matter degradation } & \multicolumn{3}{c}{ Dry matter disappearance rate } \\
& \multicolumn{3}{c}{$(\%)$} & & \multicolumn{3}{c}{$(\% / \mathrm{h})$} \\
\cline { 2 - 6 } & $24-\mathrm{h}$ & $48-\mathrm{h}$ & $72-\mathrm{h}$ & $24-\mathrm{h}$ & $48-\mathrm{h}$ & $72-\mathrm{h}$ \\
\hline U-SBM & $92.11^{\mathrm{c}}$ & $98.98^{\mathrm{c}}$ & $99.12^{\mathrm{b}}$ & $3.84^{\mathrm{c}}$ & $2.06^{\mathrm{c}}$ & $1.38^{\mathrm{b}}$ \\
$\mathrm{H}-\mathrm{SBM}$ & $42.10^{\mathrm{a}}$ & $71.58^{\mathrm{a}}$ & $87.17^{\mathrm{a}}$ & $1.75^{\mathrm{a}}$ & $1.49^{\mathrm{a}}$ & $1.21^{\mathrm{a}}$ \\
F-SBM & $52.46^{\mathrm{a}}$ & $76.57^{\mathrm{a}}$ & $94.00^{\mathrm{ab}}$ & $2.19^{\mathrm{a}}$ & $1.60^{\mathrm{a}}$ & $1.31^{\mathrm{ab}}$ \\
T-SBM & $67.66^{\mathrm{b}}$ & $91.71^{\mathrm{b}}$ & $94.11^{\mathrm{ab}}$ & $2.82^{\mathrm{b}}$ & $1.91^{\mathrm{b}}$ & $1.31^{\mathrm{ab}}$ \\
p-value & 0.001 & 0.001 & 0.05 & 0.001 & 0.001 & 0.05 \\
\hline
\end{tabular}

Means of similar letter superscripts within a column are not significantly different.

The effects of $\mathrm{H}$ treatment could be explained by the fact that heatlabile substances in feeds can be thermally deactivated, thus, increase the resistance of protein against degradation by blocking the reactive sites for microbial proteolytic enzymes (Broderick and Craig, 1980; D'Mello, 1991). The significant decrease in DMD by F treatment of SBM could be due to its effects on the rumen environment and the microbial activity (Shamoon $e t$ al., 2009). The significant reduction in rumen DMD by $\mathrm{T}$ treatment as compared to that of U-SBM across periods of incubation could be due to a possible decrease in nutrient availability by preventing attachment of rumen microbes to the plant cell walls (McAllister et al., 1994; McMahon et al., 2000). 


\section{In situ crude protein degradation of treated soybean meal}

A similar pattern of differences can be observed for CPD as that of DMD, with $\mathrm{H}$ and $\mathrm{F}$ treatments showing superiority over that of $\mathrm{T}$ treatment and the untreated especially in the first 48 hours of incubation (Table 2). Even after 72 hours of incubation, H-SBM showed the lowest degradation as compared to that of F- and T-SBM and the U-SBM, although differences were not significant, implying its effectiveness in protecting dietary protein even if the feed stays longer in the rumen. The absence of any treatment applied to SBM enabled its protein to be excessively degraded in the rumen resulting to higher overall digestibility. Crude protein disappearance rate (CPDR) showed a similar pattern of differences as that of CPD across all periods.

Table 2. Crude protein digestibility and crude protein disappearance rate analysis of treated SBM at different incubation periods.

\begin{tabular}{lcccccc}
\hline \multirow{2}{*}{ Treatments } & \multicolumn{3}{c}{ Crude protein degradation } & \multicolumn{3}{c}{ Crude protein degradation rate } \\
& \multicolumn{3}{c}{$(\%)$} & & \multicolumn{3}{c}{$(\% / \mathrm{hr})$} \\
\cline { 2 - 7 } & $24-\mathrm{h}$ & $48-\mathrm{h}$ & $72-\mathrm{h}$ & $24-\mathrm{h}$ & $48-\mathrm{h}$ & $72-\mathrm{h}$ \\
\hline $\mathrm{U}-\mathrm{SBM}$ & $93.61^{\mathrm{c}}$ & $99.81^{\mathrm{b}}$ & 99.83 & $3.90^{\mathrm{c}}$ & $2.08^{\mathrm{b}}$ & 1.39 \\
$\mathrm{H}-\mathrm{SBM}$ & $27.54^{\mathrm{a}}$ & $74.25^{\mathrm{a}}$ & 87.37 & $1.15^{\mathrm{a}}$ & $1.55^{\mathrm{a}}$ & 1.21 \\
F-SBM & $38.86^{\mathrm{a}}$ & $76.48^{\mathrm{a}}$ & 91.15 & $1.62^{\mathrm{a}}$ & $1.59^{\mathrm{a}}$ & 1.27 \\
T-SBM & $66.16^{\mathrm{b}}$ & $86.66^{\mathrm{ab}}$ & 92.63 & $2.76^{\mathrm{b}}$ & $1.81^{\mathrm{ab}}$ & 1.29 \\
p-value & 0.001 & 0.05 & 0.124 & 0.000 & 0.05 & 0.124 \\
\hline
\end{tabular}

Means with similar letter superscripts within a column are not significantly different.

The significant reduction in protein solubility in the rumen by $\mathrm{H}$ treatment must have caused denaturation, racemization, and cross-linking reactions (Friedman et al., 1984; Liu, 1999) and may have blocked the reactive sites in the SBM for microbial proteolytic enzymes. These reactions can protect the protein of H-SBM and decrease its susceptibility to microbial degradation in the rumen from $68 \%$ to $28 \%$ when the material is heated at $130^{\circ} \mathrm{C}$ (Ljøkjel et al., 2000). When H-SBM was fed, it increased milk yield of cows at early lactation (Schingoethe et al., 1988). Formaldehyde treatment can significantly protect the protein of SBM from excessive rumen degradation by way of altering the bacterial population and the pattern of fermentation through cross-linking between protein chains (Woolford, 1975).

The effect of treating SBM with $T$ which may not cause significant reduction in CPD in the rumen agrees with the findings of Nishimuta et al., 
(1974). Tannins may form hydrogen bonds with protein that are stable especially between $\mathrm{pH} 3.5$ and 8.0 in the digestive tract (Mueller-Harvey and McAllan, 1992) and reduce protein digestion, or it may change the ruminal fermentation pattern along with changes in the intestinal digestibility pattern (Frutos et al., 2004), which cause evident modifications of protein digestion from tannin ingestion.

\section{IMPLICATIONS}

The treatment of SBM to protect its protein from excessive microbial degradation in the rumen promotes more bypass protein for enzymatic digestion and absorption of AA in the small intestines. The reduction in the proteolysis of treated SBM lowers ruminal degradation of peptides and deamination of AAs also caused a more efficient utilization of $\mathrm{NH}_{3}-\mathrm{N}$ in the rumen (Newbold et al., 1990). This results to an expected 40-70\% increase in AA supply in the duodenum (Waltz and Stern, 1989), and increase milk yield in dairy animals (Bateman et al., 2005) by way of maximizing CP utilization for secretion of milk protein (Soltan, 2009). Feeding H-SBM as protein supplement in dairy animals increased milk yield and fat corrected milk by $1.5 \mathrm{~kg}$ and $1.3 \mathrm{~kg} /$ day, respectively, than the control (Socha, 1991). For feedlot fattening operation, feeding protected protein supplement promotes faster growth rate and shortens the fattening period by increasing the average daily gain and improving feed efficiency and, thus, increase the number of batches of animals per year. And among the treatment methods, $\mathrm{H}$ treatment is environment-friendly and practical compared to chemical treatment methods.

\section{CONCLUSION}

Based on in situ protein degradation as affected by various treatments, $\mathrm{H}$ treatment is the most effective for SBM which, therefore, may provide the highest amount of bypass protein supply at the intestinal level. However, in situations where $\mathrm{H}$ treatment is impractical, $\mathrm{F}$ treatment of SBM can be adopted being comparable to $\mathrm{H}$ treatment in terms of reduction in ruminal DMD and CPD. The benefit of treatment is compounded when diets of these animals are poor and concentrates are expensive. 


\section{RECOMMENDATION}

When feeding protein-rich supplements such as SBM to ruminants, the meal should be heat-treated, alternatively formaldehyde-treated, to promote increased bypass protein supply in the intestines especially for lactating and fattening (feeder) ruminants that are on high plane of nutrition.

The assessment of the potential of treated SBM as a source of bypass protein would have been more meaningful if quantification of the amount of protein that actually entered into the abomasum or the intestines and the amount excreted in the feces was done. It is, therefore, recommended that further studies on the effects of treatment methods on the protection of protein supplements be conducted using abomasally- or duodenallyfistulated cattle.

\section{ACKNOWLEDGMENT}

The authors are deeply grateful to the Commission on Higher Education (CHED) for the funding support provided and to Dr. Remberto A. Patindol for assistance in the statistical analyses of data and to Dr. Lawrence M. Liao for the comments and suggestions.

\section{REFERENCES}

AGRICULTURAL RESEARCH COUNCIL. 1984. The Nutrient Requirements of Ruminant Livestock. Supplement No. 1. Commonwealth Agricultural Bureau, Slough, UK, pp. 45.

ASSOCIATION OF OFFICIAL ANALYTICAL CHEMISTS. 1993. Official Methods of Analysis ( $16^{\text {th }}$ ed.). Washington, D.C.: Association of Official Analytical Chemists.

BAE H.D., T.A. McALLISTER, J. YANKE, K.J. CHENG and A.D. MUIR. 1993. Effects of condensed tannins on endoglucanase activity and filter paper digestion by Fibrobacter succinogenes S85. Appl Environ Microb 59:2132-2138. 
BATEMAN H.G. II. and J.H. CLARK. 2000. Soybean based feeds for dairy cows. Illini DairyNet Papers. University of Illinois Extension. http://www.livestocktrail.uiuc.edu/Dairynet/paperDisplay.cfm?Conte $n t I D=327$

BATEMAN H.G. II, J.H. CLARK and M.R. MURPHY. 2005. Development of a system to predict feed protein flow to the small intestine of cattle. J. Dairy Sci. 88:282-295.

BRODERICK G.A. and W.M. CRAIG. 1980. Effect of heat treatment on ruminal degradation and escape and intestinal digestibility of cottonseed meal.J. Nutr., 110:2381-2389.

D'MELLO J.P.F. 1991. Nutritional potentialities of fodder trees and fodder shrubs as protein sources in monogastric nutrition. Proceedings of the FAO Expert Consultation held at the Malaysian Agricultural Research and Development Institute (MARDI) (Editors: Andrew Speedy and Pierre-Luc Pugliese) Kuala Lumpur, Malaysia, 14-18 October 1991 M23 ISBN 92-5-103203-3.

FRIEDMAN M., C.E. LEVIN and A.T. NOMA. 1984. Factors governing lysinoalanine formation in soy proteins. J. Food Sci. 49:1282-1288.

FRUTOS P., G. HERVÁS, F.J. GIRÁLDEZ and A.R. MANTECÓN. 2004. Review. Tannins and ruminant nutrition. Spanish Journal of Agricultural Research 2:191-202.

GLIMP H. A., M.R. KARR, C.O. LITTLE, P.G. WOOLFOLK, G.E. MITCHELL, JR. and L.W. HUDSON. 1967. Effect of reducing soybean protein solubility by dry heat on the protein utilization of young lambs. J. Anim. Sci., 26:858.

HATFIELD E.E., A. DRIEDGER, U.S. GARRIGUS, P.E. LAMB and B.B. DOANE. 1969. Effect of treating soybean meal with tannins. Beef Day Rep. University of Illinois, Urbana-Champaign.

HEMSLEY J.A., J.P. HOGAN and T.H. WESTON. 1970. Protection of forage protein from ruminal degradation. Proc. XII Int. Grassland Congr. 11:703. 
JONES G.A., T.A. McALLISTER, A.D. MUIR and K.J. CHENG. 1994. Effects of sainfoin (Onobrychis viciifolia Scop.) condensed tannins on growth and proteolysis by four strains of ruminal bacteria. Appl. Environ. Microb., 60:1374-1378.

KEARL L.C. 1982. Nutrient requirements of ruminants in developing countries. International Feedstuffs Institute, Utah Agricultural Experiment Station, Utah University, Logan, Utah.

LENG R. A. 1997. Tree foliage in ruminant nutrition. Food and Agriculture Organization of the United Nations Rome. M-23 ISBN 92-5-104086-9.

LIN C. and L. KUNG, JR. 1997. Heat treated soybeans and soybean meal in ruminant nutrition. American Soybean Association Technical Bulletin. Vol.AN15-1997.

LIU K. 1999. Chemistry and nutritional value of soybean components. Soybeans: Chemistry, Technology and Utilization. Monsanto, ed. Aspen Publishers, Gaithersburg, MD. pp. 25-114.

LJØKJEL K., O.M. HARSTAD and A. SKREDE. 2000. Effect of heat treatment of soybean meal and fish meal on amino acid digestibility in mink and dairy cows. Anim. Feed Sci. Technol., 84:83-95.

MARTÍNEZ T.F., F.J. MOYANO, M. DÍAZ, F.G. BARROSO and F.J. ALARCÓN. 2004. Ruminal degradation of tannin-treated legume meals. Journal of the Science of Food and Agriculture. 84:1979:1987

McALLISTER T.A., BAE H.D., JONES G.A., CHENG K.J., 1994. Microbial attachment and feed digestion in the rumen.J.Anim. Sci., 72, 3004-3018.

McMAHON L.R., T.A. McALLISTER, B.P. BERG, W. MAJAK, S.N. ACHARYA, J.D. POPP, B.E. COULMAN, Y. WANG and K.J. CHENG. 2000. A review of the effects of forage condensed tannins on ruminal fermentation and bloat in grazing cattle. Can J Plant Sci., 80:469-485.

MUELLER-HARVEY I. and A.B. McALLAN A.B. 1992. Tannins. Their biochemistry and nutritional properties. In: Advances in plant cell biochemistry and biotechnology, Vol. 1 (Morrison I.M., ed.). JAI Press Ltd., London (UK), pp. 151-217. 
NATIONAL RESEARCH COUNCIL. 2001. Nutrient Requirements of Dairy Cattle. 7th Rev. Ed. Nat. Acad. Press, Washington, DC.

NEWBOLD C.J., R.J. WALLACE and N. McKAIN. 1990. Effects of the ionophore tetronasin on nitrogen metabolism by ruminal microorganisms in vitro. J. Anim. Sci. 68: 1103-1111.

NIMRICK K., E.E. HATFIELD, J. KAMINSKI and F.N. OWENS. 1970. Qualitative assessment of supplemental amino acids for growing lambs fed urea as the sole nitrogen source.J. Nutr. 100: 1293-1298.

NISHIMUTA J.F., D.G. ELY and J.A. BOLING. 1974. Ruminal bypass of dietary soybean protein treated with heat, formalin and tannic acid.J. Anim Sci. 39:952-957.

NOBAR R.S., M. CHAMANI, A.A. SADEGHI and A.M. AGHAZADEH. 2009.Determination of degradability of treated soybean meal and its proteins fractions. African Journal of Biotechnology. 8:098-102.

OSUJI P.O., I.V. NSAHLAI and H. KHALILI. 1993. Feed evaluation. ILCA Manual 5. ILCA (International Livestock Centre for Africa), Addis Ababa, Ethiopia. pp. 40.

PLAYNE M.J., W. KHUMNUALTHONG and M.G. ECHEVARRIA. 1978. Factors affecting the digestion of oesophageal fistula samples and hay samples in nylon bags in the rumen of cattle. The Journal of Agricultural Science 90:193-204.

PRESTON T.R. 1986. Better utilization of crop residues and by-products in animal feeding: Research Guidelines 2. A practical manual for research workers. Food and Agriculture Organization of the United Nations, Via delle Terme di Caracalla, 00100 Rome, Italy. ISBN 92-5-102422-7

SCHINGOETHE D.J., D.P. CASPER, C. YANG, D.J. ILLG, J.L. SOMMERFELDT and C.R. MUELLER. 1988. Lactational response to soybean meal, and extruded soybeans with ruminally protected methionine. J. Dairy Sci., 71:173-180. 
SCHWAB C.G. 1995. Protected proteins and amino acids for ruminants. In Biotechnology in animal feeds and animal feeding. VCH, NY. pp. 115.

SHAMOON S.A., M.N. SALEH and N.Y. ABBO. 2009. Effects of different levels of protein treated with formaldehyde on nutrients digestibility and some rumen and blood parameters in Awassi sheep. Iraqi J. Vet. Sci. Vol. 23, Supp. II, 2009 pp.169-173.

SOCHA M. 1991. Effect of feeding heat processed whole soybeans on milk production, milk composition and milk fatty acid profile. MS Thesis, Univ. Wisconsin, Madison, WI.

SOLTAN M.A. 2009. Rumen fermentation characteristics and lactation performance in dairy cows fed different rumen protected soybean meal products. Pakistan Journal of Nutrition 8: 695-703.

UNITED STATES DEPARTMENT OF AGRICULTURE-NATIONAL AGRICULTURAL STATISTICS SERVICE. 2004. Agricultural Statistics 2004: Oilseeds, Fats and Oils. USDA-NASS, Washington, DC. http://usda.gov/nass/pubs/agr04/acro04.htm

WALTZ D.M. and M.D. STERN. 1989. Evaluation of various methods for predicting soy-bean protein from degradation by rumen bacteria. Anim. Feed Sci. Technol. 25: 111-122.

WINA E, TANGENDJAJA B. and DUMARIA. 2008: Effect of Calliandra calothyrsus on in vitro digestibility of soybean meal and tofu wastes. Vol. 20, Article \#98. Retrieved July 26, 2011, from http://www.lrrd.org/lrrd20/6/wina20098.htm

WOOLFORD M K. 1975. Microbiological screening of food preservatives, cold sterilants and specific antimicrobial agents as potential silage additives.J. Sci. Food Agric. 26:229. 